\title{
Voltammetric Studies on Gold Electrodes Coated with Chitosan-Containing Layer-by-Layer Films
}

\author{
Shigehiro Takahashi ${ }^{1}$, Ryota Watahiki ${ }^{1}$, Kohji Tomida ${ }^{1}$, Baozhen Wang ${ }^{1,2}$ and Jun-ichi Anzai ${ }^{1, *}$ \\ 1 Graduate School of Pharmaceutical Sciences, Tohoku University, Aramaki, Aoba-ku, \\ Sendai 980-8578, Japan; E-Mails: t-shigehiro@m.tohoku.ac.jp (S.T.); \\ b2ym1036@s.tohoku.ac.jp (R.W.); a8yb1058@s.tohoku.ac.jp (K.T.) \\ 2 Department of Nutrition and Food Hygiene, School of Public Health, Shandong University, \\ 44 WenhuaXilu, Jinan, Shandong 250012, China; E-Mail: bzhenw@ hotmail.com \\ * Author to whom correspondence should be addressed; E-Mail: junanzai@m.tohoku.ac.jp; \\ Tel.: +81-22-795-6841; Fax: +81-22-795-6840.
}

Received: 30 September 2013; in revised form: 11 November 2013 / Accepted: 15 November 2013 / Published: 21 November 2013

\begin{abstract}
Gold ( $\mathrm{Au}$ ) electrodes coated with layer-by-layer (LbL) thin films composed of chitosan (CHI) were prepared to evaluate the redox properties of hexaammine ruthenium ions, $\mathrm{Ru}\left(\mathrm{NH}_{3}\right)_{6}{ }^{3+}$, and ferricyanide ions, $\mathrm{Fe}(\mathrm{CN})_{6}{ }^{3-} \mathrm{LbL}$ films were prepared on an $\mathrm{Au}$ electrode by electrostatic LbL deposition using polycationic CHI and poly(vinyl sulfate) (PVS) or poly(acrylic acid) (PAA) as anionic component. Redox peak current in cyclic voltammetry of $\mathrm{Ru}\left(\mathrm{NH}_{3}\right)_{6}{ }^{3+}$ on the $\mathrm{CHI} / \mathrm{PVS}$ and $\mathrm{CHI} / \mathrm{PAA}$ film-coated electrodes increased with increasing thickness of the films. Interestingly, the cyclic voltammograms showed two pair of redox peaks, originating from $\mathrm{Ru}\left(\mathrm{NH}_{3}\right)_{6}{ }^{3+}$ diffusing across the LbL layers and from those confined in the film. The results were rationalized in terms of the electrostatic interactions between $\mathrm{Ru}\left(\mathrm{NH}_{3}\right)_{6}{ }^{3+}$ and excess negative charges in the LbL films originating from PVS and PAA. In contrast, $\mathrm{Fe}(\mathrm{CN})_{6}{ }^{3-}$ was not confined in the LbL films due to electrostatic repulsion of $\mathrm{Fe}(\mathrm{CN})_{6}{ }^{3-}$ and excess negative charges. Significant amounts of $\mathrm{Ru}\left(\mathrm{NH}_{3}\right)_{6}{ }^{3+}$ were confined in the films at $\mathrm{pH} 7.0$, whereas few ions were bound at $\mathrm{pH} 3.0$ due to the reduced net negative charge in the films. The results suggest a potential use of the CHI-containing LbL films as scaffold for immobilizing positively charged ionic species on the electrode surface.
\end{abstract}


Keywords: polysaccharide; chitosan; layer-by-layer film; cyclic voltammetry; hexaammine ruthenium ion; ferricyanide ion

\section{Introduction}

Development of modified electrodes has been a focal issue in the fields of electrochemical sensors and biosensors [1-3]. Layer-by-layer (LbL) deposited polymer films have been widely used for modifying electrode surfaces because of the wide range of available polymer types: synthetic polymers [4-6], biopolymers such as proteins [7-11], oligosaccharides and polysaccharides [12,13], and polypeptides [14]. LbL film-modified devices have found application in sensors [15-17], stimuli-sensitive systems [18,19], and controlled release [20-24].

We have recently reported redox reactions of ferricyanide ions, $\mathrm{Fe}(\mathrm{CN})_{6}{ }^{3-}$, and hexaammine ruthenium ions, $\mathrm{Ru}\left(\mathrm{NH}_{3}\right)_{6}{ }^{3+}$, on gold $(\mathrm{Au})$ electrodes modified with $\mathrm{LbL}$ films composed of anionic polysaccharides [25,26]. Redox reactions of $\mathrm{Ru}\left(\mathrm{NH}_{3}\right)_{6}{ }^{3+}$ and $\mathrm{Fe}(\mathrm{CN})_{6}{ }^{3-}$ significantly depend on the properties of the LbL films such as film thickness, surface charge, and type of polymer employed. It was also found that $\mathrm{Fe}(\mathrm{CN})_{6}{ }^{3-}$ is confined in $\mathrm{LbL}$ films composed of carboxymethylcellulose (CMC) and alginic acid (ALG) coupled with poly(amine)s. Confined $\mathrm{Fe}(\mathrm{CN})_{6}{ }^{3-}$ was successfully used as an electrocatalyst for the oxidation of ascorbic acid [27]. In contrast, redox reaction of $\mathrm{Ru}\left(\mathrm{NH}_{3}\right)_{6}{ }^{3+}$ in the CMC- and ALG-based LbL films is severely suppressed, suggesting that CMC- and ALG-based films contain net positive charge originating from ammonium groups in the poly(amine)s in the LbL films [25,26]. In this situation, it is interesting to study the voltammetric response of the redox ions on electrodes coated with LbL films where cationic polysaccharides have been used in place of anionic CMC and ALG. For this goal, in the present study, we have employed chitosan (CHI) as a prototype of cationic polysaccharides by coupling with poly(vinyl sulfate) (PVS) or poly(acrylic acid) (PAA) to construct LbL film-modified electrodes. $\mathrm{CHI}$ is a deacetylated product of the naturally occurring polysaccharide chitin; it has been attracting much attention as a component of LbL film because of its interesting properties such as biocompatibility, high swelling ability, and antibacterial activities [28-31]. Redox properties of $\mathrm{Ru}\left(\mathrm{NH}_{3}\right)_{6}{ }^{3+}$ and $\mathrm{Fe}(\mathrm{CN})_{6}{ }^{3-}$ on the CHI/PVS and CHI/PAA film-modified electrodes may be different from those on the CMC and ALG film-modified electrodes. In fact, we have found that $\mathrm{Ru}\left(\mathrm{NH}_{3}\right)_{6}{ }^{3+}$ is electrostatically confined in the $\mathrm{LbL}$ films whereas $\mathrm{Fe}(\mathrm{CN})_{6}{ }^{3-}$ is not. This result suggests that the CHI/PVS and CHI/PAA films contain net negative charge originating from the sulfonic acid and carboxylic acid groups in PVS and PAA, respectively. The present paper reports a significant effect from the net charge in the CHI-containing LbL films on the redox properties of $\mathrm{Ru}\left(\mathrm{NH}_{3}\right)_{6}{ }^{3+}$ and $\mathrm{Fe}(\mathrm{CN})_{6}{ }^{3-}$.

\section{Experimental Section}

\subsection{Materials}

CHI (medium molecular weight) and PAA [average molecular weight (MW): 450,000] were purchased from Sigma-Aldrich Chemical Co. (St. Louis, MO, USA). PVS (MW: 240,000) and PEI 
(MW: 60,000-80,000) was purchased from Nacalai Tesque Co. (Kyoto, Japan). The chemical structures of polymeric materials used are illustrated in Figure 1. Sodium 3-mercapto-1-propanesulfonate (MPS) was purchased from Tokyo Kasei Co. (Tokyo, Japan). All other reagents were of the highest grade available and were used without further purification.

Figure 1. Chemical structures of chitosan (CHI); poly(acrylic acid) (PAA); and poly(vinyl sulfate) (PVS).

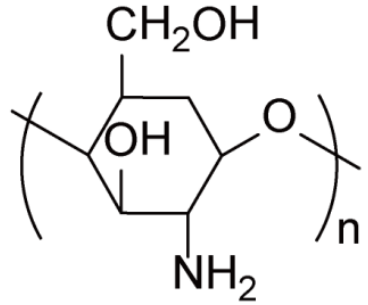

$\mathrm{CHI}$

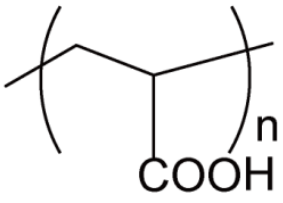

PAA

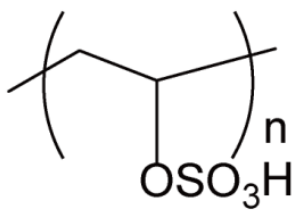

PVS

\subsection{Apparatus}

A quartz-crystal microbalance (QCM, QCA 917, Seiko EG \& G, Tokyo, Japan) was used for gravimetric analysis of LbL films. A $9 \mathrm{MHz}$ AT-cut quartz resonator coated with a thin Au layer (surface area: $0.2 \mathrm{~cm}^{2}$ ) was used as a probe, in which adsorption of $1 \mathrm{ng}$ of substance induces a $-0.91 \mathrm{~Hz}$ change in resonance frequency. Atomic force microscope (AFM, SPM-9600, Shimadzu Co., Kyoto, Japan) was used for imaging the surface of LbL films. All electrochemical measurements were carried out using an electrochemical analyzer (660B, ALS Co., Tokyo, Japan).

\subsection{Preparation of LbL Film-Coated Electrodes}

LbL films were prepared on the surface of an Au disk electrode (diameter: $3 \mathrm{~mm}$ ), according to the reported procedure [25,26]. Preparation is briefly described here. The surface of the Au electrode was polished thoroughly using alumina slurry and rinsed in distilled water before use. The polished Au electrode was treated electrochemically in a $0.5 \mathrm{M} \mathrm{H}_{2} \mathrm{SO}_{4}$ solution by scanning the potential from -0.2 to $1.5 \mathrm{~V} v s$. $\mathrm{Ag} / \mathrm{AgCl}$ at scan rate of $0.1 \mathrm{~V} \cdot \mathrm{s}^{-1}$ for $15 \mathrm{~min}$. The cleaned Au electrode was first modified with MPS by immersing the electrode in a $5 \mathrm{mM}$ MPS aqueous solution for $12 \mathrm{~h}$. The surface of the MPS-modified Au electrode was modified with a PEI precursor layer by immersing the electrode in a $0.5 \mathrm{mg} \cdot \mathrm{mL}^{-1}$ PEI aqueous solution for $15 \mathrm{~min}$ and rinsing. The PEI-modified electrode was further modified with LbL film by dipping it alternately in a $0.5 \mathrm{mg} \cdot \mathrm{mL}^{-1} \mathrm{PVS}$ or PAA solution (10 mM acetate buffer containing $150 \mathrm{mM} \mathrm{NaCl}$, pH 3.0; or $10 \mathrm{mM}$ 2-morpholinoethenesulfonic acid buffer containing $150 \mathrm{mM} \mathrm{NaCl}, \mathrm{pH} 7.0)$ and a $0.5 \mathrm{mg} \cdot \mathrm{mL}^{-1} \mathrm{CHI}$ solution $(0.5 \%$ acetic acid containing $150 \mathrm{mM} \mathrm{NaCl}, \mathrm{pH} \mathrm{5.0)}$ for $15 \mathrm{~min}$ with an intermediate $5 \mathrm{~min}$ rinse in the working buffer. The above procedure was repeated for depositing each desired layer of LbL film on the electrode. 


\subsection{Gravimetric Analysis of LbL Films}

The surface of Au-coated quartz resonator was cleaned electrochemically in $0.5 \mathrm{M} \mathrm{H}_{2} \mathrm{SO}_{4}$ as described above. LbL films were deposited on both surfaces of the quartz resonator in a manner similar to the film deposition on the Au electrode. The film-coated probe was rinsed in pure water for $1 \mathrm{~min}$ and dried in air after each deposition until the resonance frequency showed a steady-state value to estimate the weight of the film.

\subsection{AFM Imaging}

AFM images of the surface of LbL films were recorded in air at room temperature using a SPM-9600 instrument operating in dynamic (tapping) mode. The sample for AFM observation was prepared on a glass slide.

\subsection{Electrochemical Measurements}

The electrochemical response of the electrodes was measured in a glass cell using the LbL film-modified electrode as the working electrode, a platinum wire as a counter electrode, and a $\mathrm{Ag} / \mathrm{AgCl}$ electrode $(3.3 \mathrm{M} \mathrm{KCl})$ as a reference electrode. All measurements were performed under air at room temperature (approximately, $20^{\circ} \mathrm{C}$ ).

\section{Results and Discussion}

\subsection{Preparation of Chitosan-Containing LbL Films}

The deposition behavior of chitosan-containing LbL films was studied using a QCM. Figure 2a plots the decrease in the resonance frequency $(-\Delta F)$ recorded upon depositing CHI/PVS films as a function of the number of depositions. The $-\Delta F$ values increased in magnitude almost linearly as the number of depositions increased for the PEI(CHI/PVS $)_{n}$ films, suggesting that CHI and PVS were successfully deposited on the quartz resonator to form the $\mathrm{LbL}$ film. The effect of the $\mathrm{pH}$ of the PVS solution was rather small. It is clear that the PEI(CHI/PVS $)_{n}$ films formed through electrostatic affinity between positive charges on the CHI chains and negative charges on PVS. On the other hand, for the $\mathrm{PEI}(\mathrm{CHI} / \mathrm{PAA})_{n}$ films, the $-\Delta F$ magnitude increased upon depositing $\mathrm{CHI}$ but was decreased upon depositing PAA, suggesting that some of the CHI located on the outermost surface of the film was desorbed during deposition of the next PAA layer (Figure 2b). Similar adsorption-desorption behavior has been reported for some LbL films [32,33]. Another feature of the PEI(CHI/PAA $)_{n}$ films is that the deposition behavior depended on the $\mathrm{pH}$ of the PAA solution. The $-\Delta F$ values for the PEI(CHI/PAA $)_{n}$ film deposited from acidic PAA solution ( $\mathrm{pH}$ 3.0) were markedly larger than those prepared using neutral PAA solution ( $\mathrm{pH}$ 7.0), probably owing to protonation of carboxylate groups in PAA at pH 3.0. It is likely that protonated PAA assumes a coiled conformation in LbL films, resulting in thicker layers [5]. This is a clear contrast to the deposition behavior of PEI(CHI/PVS $)_{n}$ films, in which the $-\Delta F$ values did not depend on the $\mathrm{pH}$ of the PVS solution. This is because sulfonic acid groups in PVS should be fully dissociated at both $\mathrm{pH} 3.0$ and 7.0 owing to its strong acidity. The average thickness of the films prepared at $\mathrm{pH} 7.0$ was estimated from the QCM data to be about $40 \mathrm{~nm}$ for the 
$\mathrm{PEI}(\mathrm{CHI} / \mathrm{PVS})_{5}$ film and about $21 \mathrm{~nm}$ for the PEI(CHI/PAA $)_{5}$ film in the dry state; these estimates assume that the frequency changes linearly depend on the deposited mass and the density of the films is near $1.2 \mathrm{~g} \cdot \mathrm{cm}^{-3}$ [34].We used here QCM to qualitatively verify the deposition behavior of LbL films. It is known that the frequency changes in QCM depend not only on the deposited mass but also on other factors such as hydration and stiffness of the materials [35]. In fact, fluctuation in the $-\Delta F$ values in our data is rather high. Nevertheless, the QCM results show that CHI-based LbL films could be successfully constructed through electrostatic binding between CHI and PVS or PAA.

The surface morphology of LbL films was studied using AFM. Figure 3 shows three-dimensional AFM images of the surface of dry LbL films. The surface is rather rough, with the root mean square (rms) roughness being $14.2 \mathrm{~nm}$ and $13.2 \mathrm{~nm}$ for the PEI(PAA/CHI $)_{5}$ and PEI(PVS/CHI $)_{5}$ films, respectively. Both the QCM and AFM results clearly show successful preparation of the CHI-containing LbL films.

Figure 2. Frequency changes in the quartz-crystal microbalance (QCM) for deposition of (a) $\mathrm{PEI}(\mathrm{CHI} / \mathrm{PVS})_{5}$ films; and (b) $\mathrm{PEI}(\mathrm{CHI} / \mathrm{PAA})_{n}$ films at $\mathrm{pH} 3.0$ (blue) and $\mathrm{pH} 7.0$ (red). Plotted points are averages of three measurements with standard deviation.

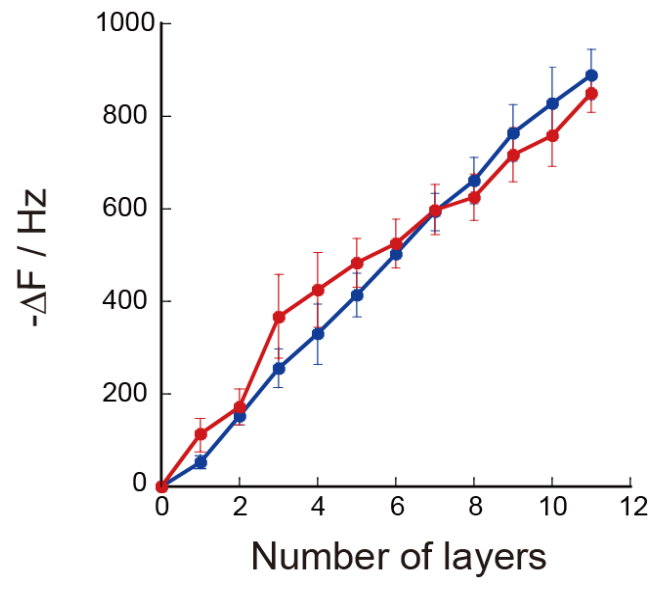

(a)

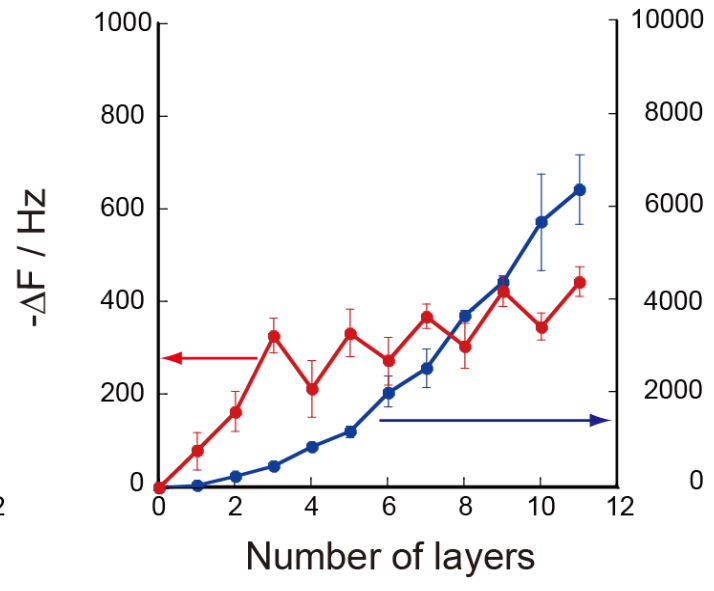

(b)

Figure 3. AFM three-dimensional images of (a) PEI(PAA/CHI $)_{5}$; and (b) PEI(PVS/CHI) films. The films were prepared using $\mathrm{pH} 7.0$ PAA and PVS solutions and $\mathrm{pH} 5.0$ CHI solution.

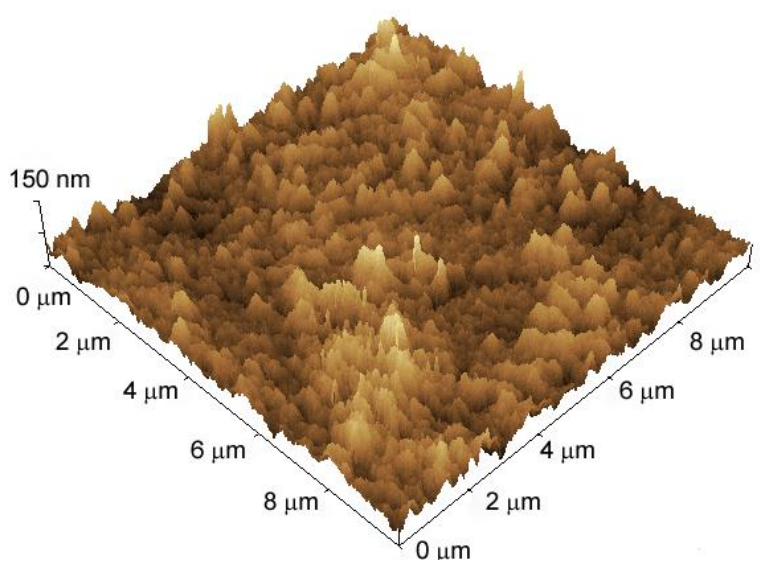

(a)

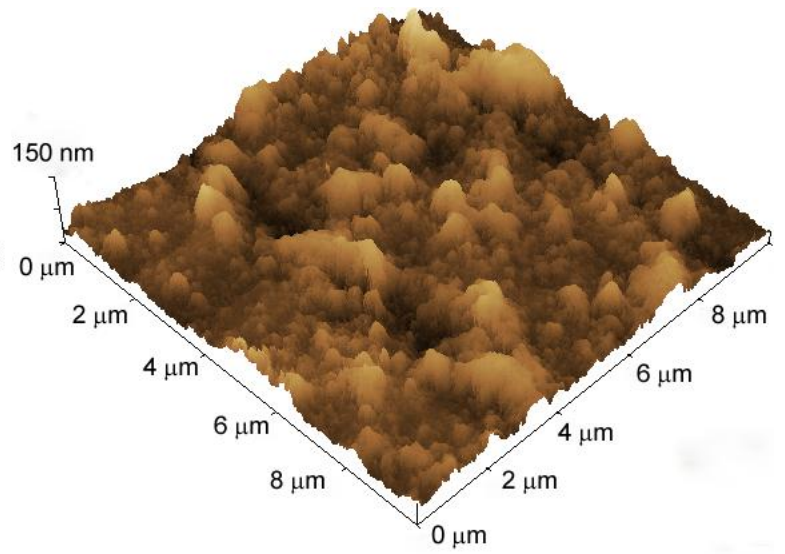

(b) 


\subsection{Redox Reactions of $\mathrm{Ru}\left(\mathrm{NH}_{3}\right)_{6}{ }^{3+}$ and $\mathrm{Fe}(\mathrm{CN})_{6}{ }^{3-}$ on $\mathrm{CHI} / \mathrm{PVS}$ and $\mathrm{CHI} / \mathrm{PAA}$}

\section{Film-Modified Electrodes}

Redox properties of CHI/PVS and CHI/PAA film-coated electrodes should be evaluated for their applications to electrochemical devices such as sensors and reactors. For this purpose, we have used $\mathrm{Ru}\left(\mathrm{NH}_{3}\right)_{6}{ }^{3+}$ and $\mathrm{Fe}(\mathrm{CN})_{6}{ }^{3-}$ as redox marker because these ions are known to be stable unless measurements are carried out in strongly acidic solutions [36]. In fact, these ions have been widely used as redox marker in voltammetric studies [37-39]. Figure 4 shows cyclic voltammograms (CVs) of $\mathrm{Ru}\left(\mathrm{NH}_{3}\right)_{6}{ }^{3+}$ on $\mathrm{Au}$ electrodes coated with PEI(PVS/CHI $)_{n} \mathrm{PVS}$ and PEI(PVS/CHI $)_{n}$ films, where $\mathrm{n}$ denotes the number of bilayers in the LbL films. The CVs were recorded after the electrode had been immersed in a $1 \mathrm{mM} \mathrm{Ru}\left(\mathrm{NH}_{3}\right)_{6}{ }^{3+}$ solution for $15 \mathrm{~min}$ because the peak current in CVs increased with time during the first several minutes. For the PEI(PVS/CHI) ${ }_{n} \mathrm{PVS}$ film-coated electrodes (Figure 4a), redox peaks were observed in the potential range of -0.1 to $-0.3 \mathrm{~V}$; these peaks are attributed to redox reactions of $\mathrm{Ru}\left(\mathrm{NH}_{3}\right)_{6}{ }^{3+}[40,41]$. The $\mathrm{CV}$ shows two oxidation peaks, at around -150 and $-250 \mathrm{mV}$. The intensity of the latter peak increased as the number of bilayers was increased. The shape and intensity of the reduction peak was also dependent on film thickness: the peak at approximately $-270 \mathrm{mV}$ increased with an accompanying shoulder peak around $-200 \mathrm{mV}$. These results suggest that two kinds of redox reactions take place concurrently in LbL films. It is worth noting that the separation between the anodic and cathodic peaks $\left(\Delta E_{\mathrm{p}}\right)$ for the redox couple around $-250 \mathrm{mV}$ was small $(10-20 \mathrm{mV})$, suggesting the $\mathrm{CV}$ peaks originate from $\mathrm{Ru}\left(\mathrm{NH}_{3}\right)_{6}{ }^{3+}$ confined in the films. In contrast, the $\Delta E_{\mathrm{p}}$ values for the redox couple at -100 to $-200 \mathrm{mV}$ were $60-80 \mathrm{mV}$, showing that these peaks might have arisen from the redox reaction of diffusing species. Consequently, both the diffusing and confined species are involved in the redox reactions of $\mathrm{Ru}\left(\mathrm{NH}_{3}\right)_{6}{ }^{3+}$ in the PEI(PVS/CHI $)_{n} \mathrm{PVS}$ films, as illustrated in Figure 5.

Figure 4. Cyclic voltammograms $(\mathrm{CVs})$ of $5 \mathrm{mM} \mathrm{Ru}\left(\mathrm{NH}_{3}\right)_{6}{ }^{3+}$ on (a) $\mathrm{PEI}(\mathrm{PVS} / \mathrm{CHI})_{n} \mathrm{PVS}$; and (b) $\mathrm{PEI}(\mathrm{PVS} / \mathrm{CHI})_{n}$ films at $\mathrm{pH}$ 7.0.

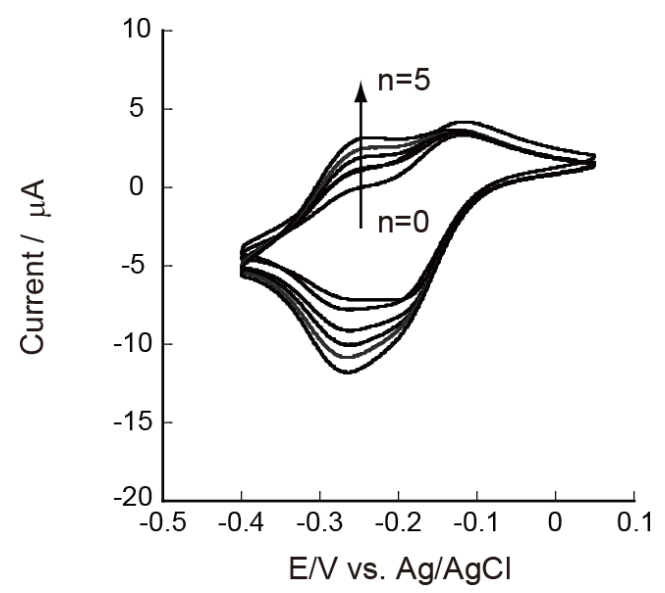

(a)

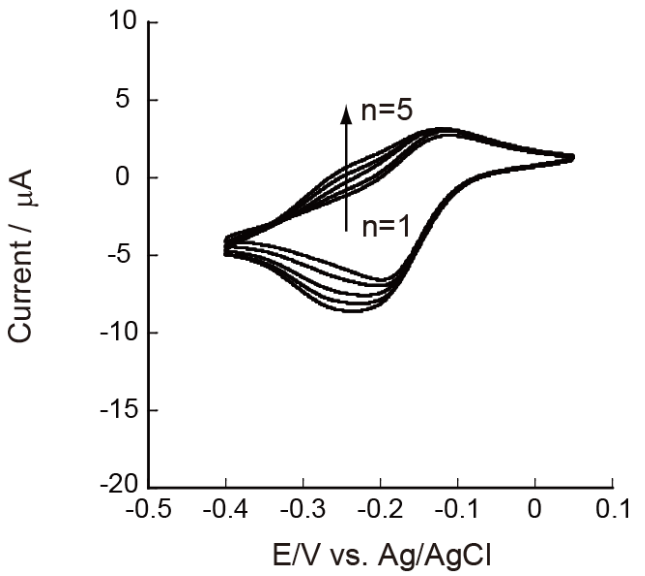

(b)

Similar CVs were observed on the electrodes coated with PEI(PVS/CHI) ${ }_{n}$ films, whose outermost surfaces were covered with positively charged CHI (Figure 4b). These results show that the $\mathrm{PEI}(\mathrm{PVS} / \mathrm{CHI})_{n} \mathrm{PVS}$ and $\mathrm{PEI}(\mathrm{PVS} / \mathrm{CHI})_{n}$ films are permeable to $\mathrm{Ru}\left(\mathrm{NH}_{3}\right)_{6}{ }^{3+}$ and that the ions are 
confined in the films, probably due to electrostatic attraction between positively charged $\mathrm{Ru}\left(\mathrm{NH}_{3}\right)_{6}{ }^{3+}$ and fixed negative charges in the films. Sulfonate residues in PVS should be responsible for the negative sites in the LbL films. It is likely that the amount of negative charge in PVS is higher than the amount of positive charge in $\mathrm{CHI}$ in the $\mathrm{PEI}(\mathrm{PVS} / \mathrm{CHI})_{n} \mathrm{PVS}$ and $\mathrm{PEI}(\mathrm{PVS} / \mathrm{CHI})_{n}$ films, providing excess negatively charged sites for binding $\mathrm{Ru}\left(\mathrm{NH}_{3}\right)_{6}{ }^{3+}$. In this context, we have previously reported that LbL films composed of negatively charged polysaccharides (CMC and ALG) and synthetic poly(amine)s contain net positive charge originating from protonated amino groups in the poly(amine)s [25,26]. The results were rationalized in terms of higher charge densities in the poly(amine)s than in the polysaccharides. It is worth noting that despite a possible electrostatic repulsion between the ions and $\mathrm{CHI}$, LbL films terminated with $\mathrm{CHI}$ are permeable to $\mathrm{Ru}\left(\mathrm{NH}_{3}\right)_{6}{ }^{3+}$, although the permeation was suppressed to some extent.

Figure 5. Schematic illustration of the redox reactions diffusing and confined $\mathrm{Ru}\left(\mathrm{NH}_{3}\right)_{6}{ }^{2+/ 3+}$ ions on the Au electrode.

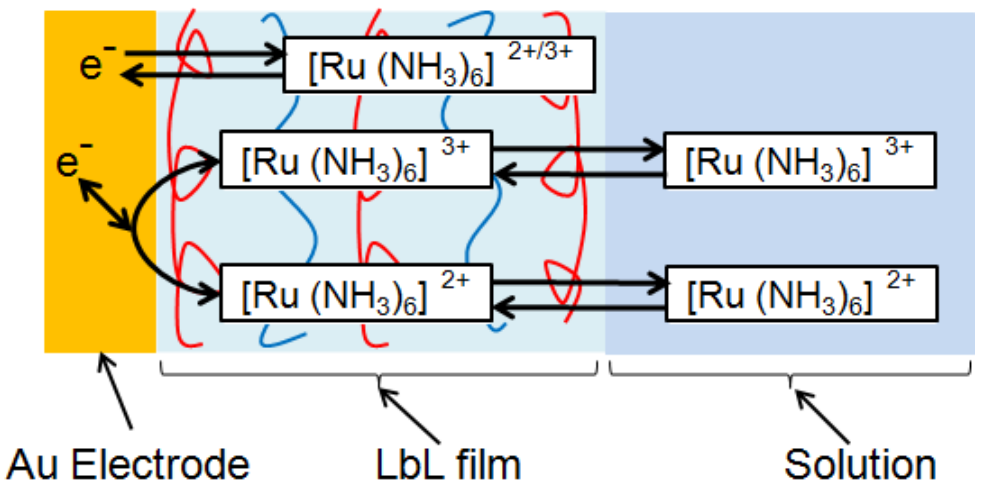

Figure 6 shows $\mathrm{CVs}$ of $\mathrm{Fe}(\mathrm{CN})_{6}{ }^{3-}$ on $\mathrm{Au}$ electrodes coated with $\mathrm{PEI}(\mathrm{PVS} / \mathrm{CHI})_{5} \mathrm{PVS}$ and $\mathrm{PEI}(\mathrm{PVS} / \mathrm{CHI})_{5}$ films. The redox reaction of $\mathrm{Fe}(\mathrm{CN})_{6}{ }^{3-}$ was strongly suppressed, suggesting that the LbL films are less permeable to negatively charged $\mathrm{Fe}(\mathrm{CN})_{6}{ }^{3-}$. These results support the view that the $\mathrm{PEI}(\mathrm{PVS} / \mathrm{CHI})_{5} \mathrm{PVS}$ and $\mathrm{PEI}(\mathrm{PVS} / \mathrm{CHI})_{5}$ films contain excess negative charges.

Figure 6. $\mathrm{CVs}$ of $5 \mathrm{mM} \mathrm{Fe}(\mathrm{CN})_{6}{ }^{3-}$ ions on (a) PEI(PVS/CHI $)_{n} \mathrm{PVS}$; and (b) PEI(PVS/CHI $)_{n}$ films at $\mathrm{pH} 7.0$.

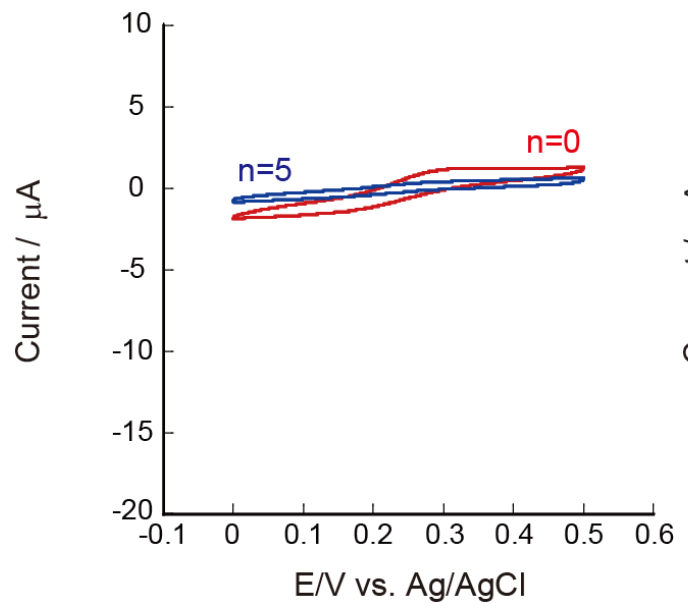

(a)

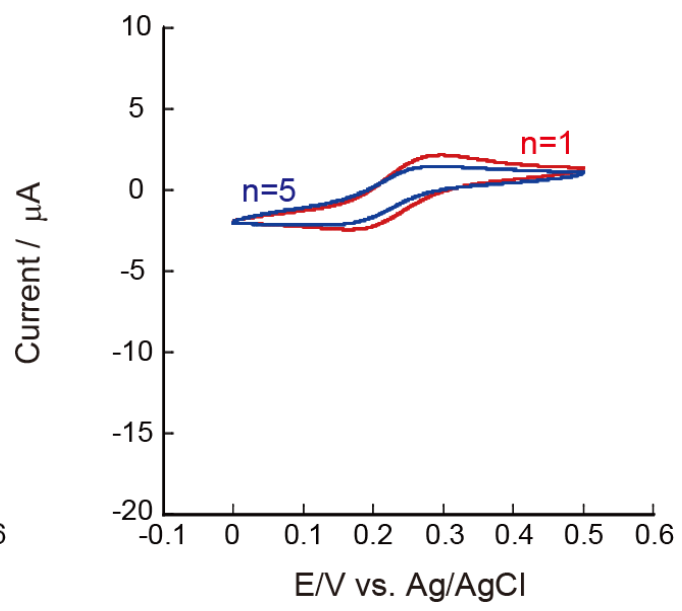

(b) 
The effects of type of polyanion in the film were studied using PAA in place of PVS. Figure 7 shows $\mathrm{CVs}$ of $\mathrm{Ru}\left(\mathrm{NH}_{3}\right)_{6}{ }^{3+}$ recorded on the PEI(PAA/CHI $)_{n} \mathrm{PAA}$ and PEI(PAA/CHI $)_{n}$ film-coated electrodes. The characteristic features of the CVs were largely similar to those observed for the PVS-based films, except that in contrast to the PVS-based films, two anodic peaks were not clearly observed. Instead, the anodic peak current increased as the apparent $E_{\mathrm{p}}$ values shifted in the negative direction. The broad peaks might be composed of two kinds of redox peaks originating from diffusing and confined $\mathrm{Ru}\left(\mathrm{NH}_{3}\right)_{6}{ }^{3+}$.

Figure 7. $\mathrm{CVs}$ of $5 \mathrm{mM} \mathrm{Ru}\left(\mathrm{NH}_{3}\right)_{6}{ }^{3+}$ on (a) PEI(PAA/CHI ${ }_{n} \mathrm{PAA}$; and (b) $\mathrm{PEI}(\mathrm{PAA} / \mathrm{CHI})_{n}$ films at $\mathrm{pH}$ 7.0.

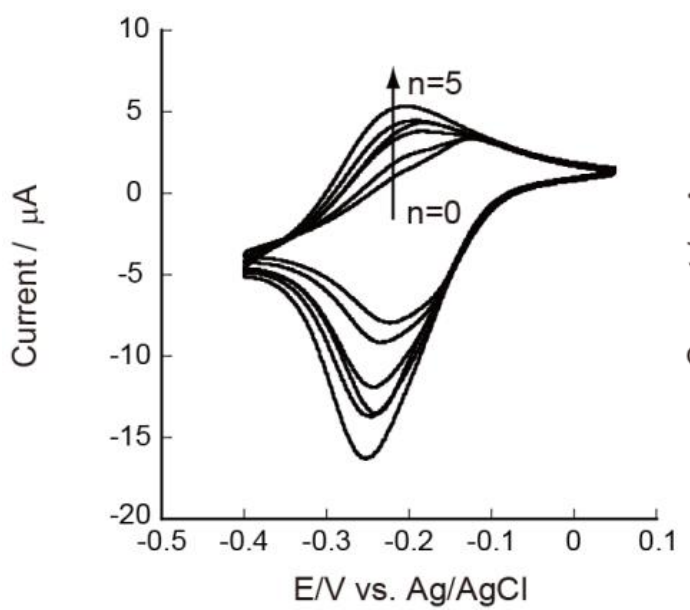

(a)

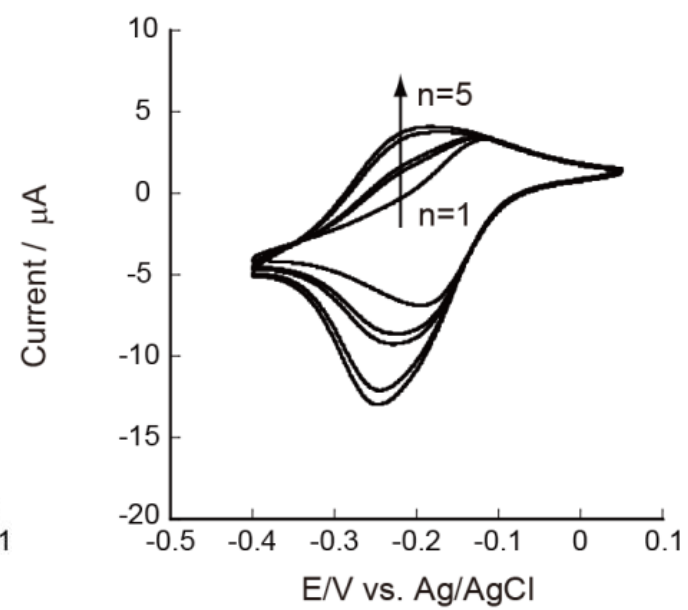

(b)

\subsection{Effects of $p H$ on the Redox Reactions of $\mathrm{Ru}\left(\mathrm{NH}_{3}\right)_{6}{ }^{3+}$}

It is interesting to evaluate the effects of $\mathrm{pH}$ on the redox reactions of $\mathrm{Ru}\left(\mathrm{NH}_{3}\right)_{6}{ }^{3+}$ on the $\mathrm{LbL}$ film-coated electrodes, because the amount of electric charge from $\mathrm{CHI}$ and PAA in the film should depend on the $\mathrm{pH}$ of the solution. In other words, the microenvironment in the LbL films is $\mathrm{pH}$-dependent. Figure 8 shows the $\mathrm{CV}$ s of $\mathrm{PEI}(\mathrm{PVS} / \mathrm{CHI})_{5}$ and $\mathrm{PEI}(\mathrm{PAA} / \mathrm{CHI})_{5}$ film-coated electrodes in $0.5 \mathrm{mM}\left[\mathrm{Ru}\left(\mathrm{NH}_{3}\right)_{6}\right]^{3+}$ solutions at $\mathrm{pH} 7.0$ and 3.0. In this experiment, the PEI(PVS/CHI $)_{5}$ and $\mathrm{PEI}(\mathrm{PAA} / \mathrm{CHI})_{5}$ films were prepared using $\mathrm{pH}$ 7.0 PVS and PAA solutions. The anodic and cathodic currents in the $\mathrm{CVs}$ for the $\mathrm{PEI}(\mathrm{PVS} / \mathrm{CHI})_{5}$ film-coated electrode were suppressed in the acidic solution (Figure $8 \mathrm{a}$ ). The redox couple found at -250 to $-300 \mathrm{mV}$ at $\mathrm{pH} 7.0$ was only weakly observed at $\mathrm{pH}$ 3.0. These results suggest that the amount of $\mathrm{Ru}\left(\mathrm{NH}_{3}\right)_{6}{ }^{3+}$ confined in the film is negligibly small at $\mathrm{pH}$ 3.0, probably due to increased number of positive charges as a result of protonation to amino groups in CHI. The $\mathrm{CVs}$ for the PEI(PAA/CHI $)_{5}$ film-coated electrode also depended on the $\mathrm{pH}$ (Figure 8b). In the acidic solutions at $\mathrm{pH}$ 3.0, the $\mathrm{CV}$ exhibited typical diffusion-controlled waveforms, showing $\mathrm{Ru}\left(\mathrm{NH}_{3}\right)_{6}{ }^{3+}$ could not be confined at the acidic $\mathrm{pH}$. This is attributed to the reduced number of negative charges in the PAA chains as well as the increased positive charge in $\mathrm{CHI}$ in the acidic solution. Thus, the PEI(PAA/CHI $)_{5}$ film might not contain excess negative sites, meaning that no $\mathrm{Ru}\left(\mathrm{NH}_{3}\right)_{6}{ }^{3+}$ could be confined at $\mathrm{pH} 3.0$.

The LbL films prepared using acidic PVS and PAA solutions may exhibit different properties from those prepared at $\mathrm{pH}$ 7.0. In particular, the $\mathrm{pH}$-dependent QCM results (Figure 1) suggest that the 
effects may be significant for the PEI(PAA/CHI $)_{5}$ films. Figure 9 shows the $\mathrm{CVs}$ of $\mathrm{Ru}\left(\mathrm{NH}_{3}\right)_{6}{ }^{3+}$ on the $\mathrm{PEI}(\mathrm{PVS} / \mathrm{CHI})_{5}$ and PEI(PAA/CHI $)_{5}$ film-coated electrodes, in which the LbL films were prepared using pH 3.0 PVS and PAA solutions. The CVs for the PEI(PVS/CHI $)_{5}$ film-coated electrode were similar to those prepared using $\mathrm{pH} 7.0$ solutions (see Figure 8a). It is likely that the PEI(PVS/CHI $)_{5}$ films prepared at $\mathrm{pH} 3.0$ and 7.0 bear a structural resemblance to each other; this would be consistent with the QCM results (see Figure 1). In contrast, for the PEI(PAA/CHI) 5 film-coated electrode prepared at $\mathrm{pH} 3.0$, the redox current was significantly higher than that recorded on the electrode prepared at $\mathrm{pH}$ 7.0. The higher redox response on the electrode prepared at $\mathrm{pH} 3.0$ relates to thickness of the films. (The thickness of the PEI(PAA/CHI) $)_{5}$ film prepared at $\mathrm{pH} 3.0$ is calculated by QCM to be

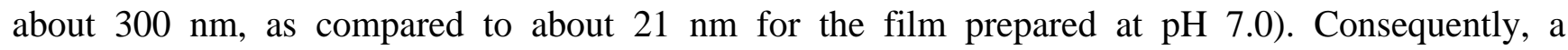
higher amount of $\mathrm{Ru}\left(\mathrm{NH}_{3}\right)_{6}{ }^{3+}$ can be immobilized in the thicker film, resulting in the enhanced redox response.

Figure 8. $\mathrm{CVs}$ of $\mathrm{Ru}\left(\mathrm{NH}_{3}\right)_{6}{ }^{3+}$ on (a) PEI(PVS/CHI $)_{5}$; and (b) PEI(PAA/CHI $)_{5}$ film-coated electrodes at $\mathrm{pH} 3.0$ (blue) and $\mathrm{pH} 7.0$ (red). The LbL films were prepared at $\mathrm{pH}$ 7.0.

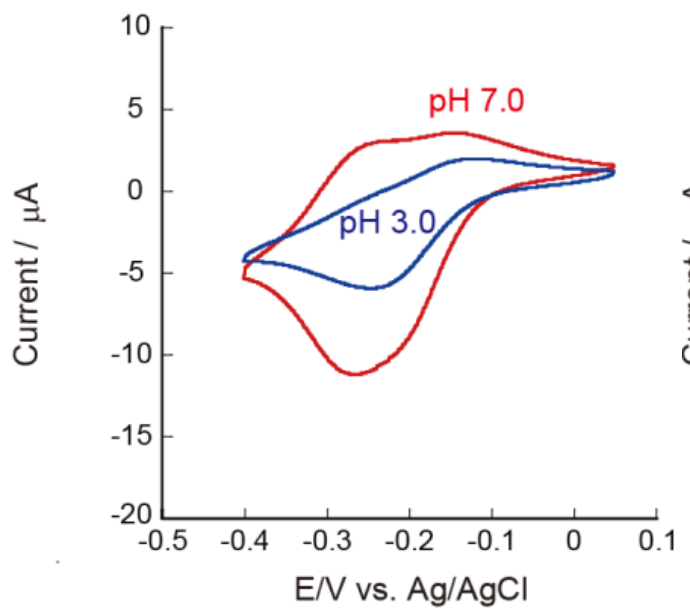

(a)

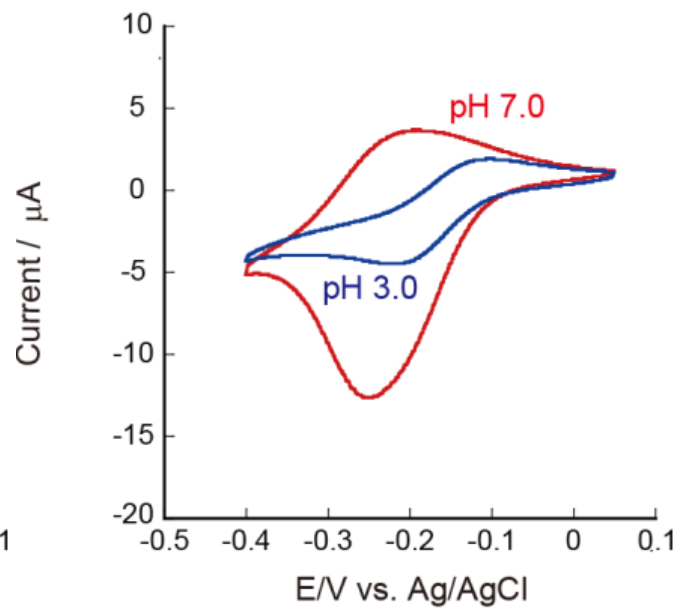

(b)

Figure 9. $\mathrm{CVs}$ of $\mathrm{Ru}\left(\mathrm{NH}_{3}\right)_{6}{ }^{3+}$ on (a) $\mathrm{PEI}(\mathrm{PVS} / \mathrm{CHI})_{5}$; and (b) $\mathrm{PEI}(\mathrm{PAA} / \mathrm{CHI})_{5}$ film-coated electrodes at $\mathrm{pH} 3.0$ (blue) and $\mathrm{pH} 7.0$ (red). The LbL films were prepared at $\mathrm{pH} 3.0$.

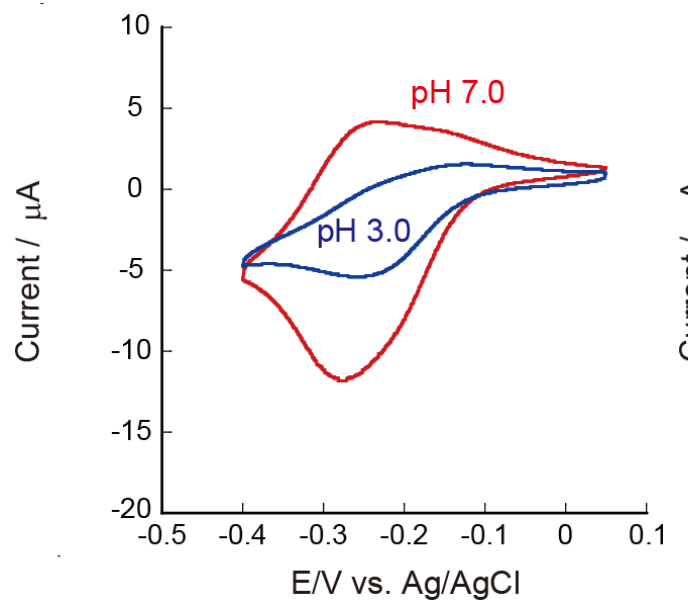

(a)

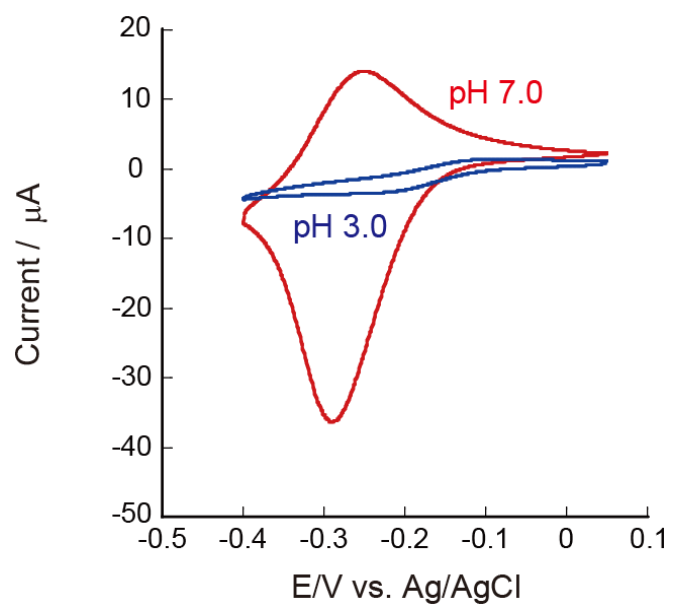

(b) 


\subsection{Stability of $\mathrm{Ru}\left(\mathrm{NH}_{3}\right)_{6}{ }^{3+}$ Confined in LbL Films}

The stability of the $\mathrm{Ru}\left(\mathrm{NH}_{3}\right)_{6}{ }^{3+}$ confined in the $\mathrm{LbL}$ film was evaluated by monitoring the redox current in the CVs. The electrodes were stored in the working buffer at $\mathrm{pH} 7.0$, containing either 10 or $150 \mathrm{mM} \mathrm{NaCl}$ when not being used for measurement. The peak current decreased rapidly immediately after preparation, suggesting a significant portion of confined $\mathrm{Ru}\left(\mathrm{NH}_{3}\right)_{6}{ }^{3+}$ was released rapidly out of the films. In the buffer solution with $150 \mathrm{mM} \mathrm{NaCl}$, about $70 \%$ of the $\mathrm{Ru}\left(\mathrm{NH}_{3}\right)_{6}{ }^{3+}$ was released out of the film after $30 \mathrm{~min}$. Thereafter, the release of $\mathrm{Ru}\left(\mathrm{NH}_{3}\right)_{6}{ }^{3+}$ from the film slowly continued, and only $5 \%-10 \%$ of the $\mathrm{Ru}\left(\mathrm{NH}_{3}\right)_{6}{ }^{3+}$ remained in the films after $20 \mathrm{~h}$. The release of the ions was slightly suppressed in the medium containing $10 \mathrm{mM} \mathrm{NaCl} ; 20 \%-30 \%$ of the $\mathrm{Ru}\left(\mathrm{NH}_{3}\right)_{6}{ }^{3+}$ was retained in the film after $20 \mathrm{~h}$. This is probably because ion exchange between $\mathrm{Ru}\left(\mathrm{NH}_{3}\right)_{6}{ }^{3+}$ and $\mathrm{Na}^{+}$in the film is suppressed in the $10 \mathrm{mM} \mathrm{NaCl}$ solution.

In a separate experiment, we found that uptake of $\mathrm{Ru}\left(\mathrm{NH}_{3}\right)_{6}{ }^{3+}$ in the $\mathrm{LbL}$ films was reversible. In fact, confinement of $\mathrm{Ru}\left(\mathrm{NH}_{3}\right)_{6}{ }^{3+}$ in the films could be done repeatedly by immersing the LbL film-coated electrodes in a $1 \mathrm{mM} \mathrm{Ru}\left(\mathrm{NH}_{3}\right)_{6}{ }^{3+}$ solution at $\mathrm{pH} 7.0$ after $\mathrm{Ru}\left(\mathrm{NH}_{3}\right)_{6}{ }^{3+}$ had been fully released.

\section{Conclusions}

We have demonstrated that $\mathrm{Ru}\left(\mathrm{NH}_{3}\right)_{6}{ }^{3+}$ permeates $\mathrm{LbL}$ films composed of CHI and PVS or PAA, irrespective of the sign of electric charge on the film surface, suggesting that the CHI/PVS and CHI/PAA films contain net negative charge. $\mathrm{Ru}\left(\mathrm{NH}_{3}\right)_{6}{ }^{3+}$ could be confined in the LbL films, providing supporting evidence for the existence of excess negative charges in the LbL films. In contrast, $\mathrm{Fe}(\mathrm{CN})_{6}{ }^{3-}$ could not be confined in the LbL films due to a lack of electrostatic affinity to the films. Consequently, the present study, together with our previous studies [25,26], clearly demonstrates that the sign of net electric charge in polysaccharide LbL films can be tuned by an appropriate choice of polysaccharide type. Therefore, CHI-containing LbL films may be useful as scaffolds for immobilizing positively charged species, such as catalysts, on an electrode surface.

\section{Acknowledgments}

This work was supported in part by Japan Society for the Promotion of Science Grants-in-Aid for Scientific Research Grant Number 24659013.

\section{Conflicts of Interest}

The authors declare no conflict of interest.

\section{References}

1. Zheng, D.; Vashist, S.K.; Dykas, M.M.; Saha, S.; Al-Rubeaan, K.; Lam, E.; Luong, J.H.T.; Sheu, F.S. Graphene versus multi-walled carbon nanotubes for electrochemical glucose biosensing. Materials 2013, 6, 1011-1027.

2. Janssen, K.P.F.; Knez, K.; Spasic, D.; Lammertyn, J. Nucleic acid for ultra-sensitive protein detection. Sensors 2013, 13, 1353-1384. 
3. Wang, Y.; Hasebe, Y. Uricase-adsorbed carbon-felt reactor coupled with a peroxidase-modified carbon-felt-based $\mathrm{H}_{2} \mathrm{O}_{2}$ detector for highly sensitive amperometric flow determination of uric acid. J. Pharmaceut. Biomed. Anal. 2012, 57, 125-132.

4. Lvov, Y.; Decher, G.; Möhwald, H. Assembly, structural characterization, and thermal behavior of layer-by-layer deposited ultrathin films of poly(vinyl sulfate) and poly(allylamine). Langmuir 1993, 9, 481-486.

5. Shiratori, S.S.; Rubner, M.F. pH-dependent thickness behavior of sequentially adsorbed layers of weak polyelectrolytes. Macromolecules 2000, 33, 4213-4219.

6. Suzuki, I.; Egawa, Y.; Mizukawa, Y.; Hoshi, T.; Anzai, J. Construction of positively-charged layered assemblies assisted by cyclodextrin complexation. Chem. Commun. 2002, 21, $164-165$.

7. Hoshi, T.; Akase, S.; Anzai, J. Preparation of multilayer thin films containing avidin through sugar-lectin interactions and their binding properties. Langmuir 2002, 18, 7024-7028.

8. Vogt, C.; Mertz, D.; Benmlih, K.; Hemmerlé, J.; Voegel, J.-C.; Schaaf, P.; Lavalle, P. Layer-by-layer enzymatic platform for stretched-induced reactive release. ACS Macro Lett. 2012, 21, 797-801.

9. Liu, J.; Wang, Q.; Fan, X.R.; Sun, X.J.; Huang, P.H. Layer-by-layer self-assembly immobilization of catalases on wool fabrics. Appl. Biochem. Biotechnol. 2013, 169, 2212-2222.

10. Kong, J.; Lu, Z.; Lvov, Y.M.; Desamero, R.Z.B.; Frank, H.A.; Rusling, J.F. Direct electrochemistry of cofactor redox sites in a bacterial photosynthetic reaction center protein. J. Am. Chem. Soc. 1998, 120, 7371-7372.

11. Lvov, Y. Electrostatic layer-by-layer assembly of proteins and polyions. In Protein Architectures: Inter Facial Molecular Assemblies and Immobilization Biotechnology; Lvov, Y., Möhwald, H., Eds.; Marcel Dekker: New York, NY, USA, 1999; pp. 135-137.

12. Sato, K.; Suzuki, I.; Anzai, J. Preparation of polyelectrolyte-layered assemblies containing cyclodextrin and their binding properties. Langmuir 2003, 19, 7406-7412.

13. Gribova, V.; Auzey-Velty, R.; Picart, C. Polyelectrolyte multilayer assemblies on materials surfaces: From cell adhesion to tissue engineering. Chem. Mater. 2011, 24, 854-869.

14. Zhou, D.; Xiao, H.; Meng, F.; Zhou, S.; Guo, J.; Li, X.; Jing, X.; Huang, Y. Layer-by-layer assembled polypeptide capsules for platinum-based pro-drug delivery. Bioconjugate Chem. 2012, 23, 2335-2343.

15. Liu, A.; Anzai, J. Ferrocene-containing polyelectrolyte multilayer films: Effects of electrochemically inactive surface layers on the redox properties. Langmuir 2003, 19, 4043-4046.

16. Takahashi, S.; Sato, K.; Anzai, J. Layer-by-layer construction of protein architectures through avidin-biotin and lectin-sugar interactions for biosensor applications. Anal. Bioanal. Chem. 2012, $402,1749-1758$.

17. Zheng, H.; Zhou, J.; Okezaki, Y.; Suye, S. Construction of L-lysine sensor by layer-by-layer adsorption of L-lysine 6-dehydrogenase and ferrocene-labeled high molecular weight coenzyme derivative on gold electrode. Electroanalysis 2008, 20, 2685-2691.

18. Sato, K.; Kodama, D.; Naka, Y.; Anzai, J. Electrochemically induced disintegration of layer-by-layer-assembled thin films composed of 2-iminobiotin-labeled poly(ethyleneimine) and avidin. Biomacromolecules 2006, 7, 3302-3305. 
19. Sukhishvili, S.A. Responsive polymer films and capsules via layer-by-layer assembly. Curr. Opin. Colloid Interf. Sci. 2005, 10, 37-44.

20. Inoue, H.; Anzai, J. Stimuli-sensitive thin films prepared by a layer-by-layer deposition of 2-iminobiotin-labeled poly(ethyleneimine) and avidin. Langmuir 2005, 21, 8354-8359.

21. Wood, K.C.; Zacharie, N.S.; Schmidt, D.J.; Wrightman, S.N.; Andaya, B.J.; Hammond, P.T. Electroactive controlled release thin films. Proc. Natl. Acad. Sci. USA 2008, 105, 2280-2285.

22. Esser-Kahn, A.P.; Odom, S.A.; Scotts, N.R.; White, S.R.; Moore, J.S. Triggered release from polymer capsules. Macrommolecules 2011, 44, 5539-5553.

23. Manna, U.; Patil, S. Glucose-triggered drug delivery from boronate mediated layer-by-layer self-assembly. ACS Appl. Mater. Interf. 2010, 2, 1521-1527.

24. Sato, K.; Takahashi, S.; Anzai, J. Layer-by-layer thin films and microcapsules for biosensors and controlled release. Anal. Sci. 2012, 28, 929-938.

25. Noguchi, T.; Anzai, J. Redox properties of the ferricyanide ion on electrodes coated with layer-by-layer thin films composed of polysaccharide and poly(allylamine). Langmuir 2006, 22, 2870-2875.

26. Wang, B.; Anzai, J. Redox reactions of ferricyanide ions in layer-by-layer deposited polysaccharide films: A significant effect of the type of polycation in the films. Langmuir 2007, $23,7378-7384$.

27. Wang, B.; Noguchi, T.; Anzai, J. Layer-by-layer thin film-coated electrodes for electrocatalytic determination of ascorbic acid. Talanta 2007, 72, 415-418.

28. Yilmaz, E. Chitosan: A versatile biomaterial. Adv. Exp. Med. Biol. 2004, 553, 59-68.

29. Lu, H.; Hu, N. Loading behavior of $\{\text { chitosan/hyaluronic acid }\}_{n}$ layer-by-layer assembly films toward myoglobin: and electrochemical study. J. Phys. Chem. B 2006, 110, 23710-23718.

30. Lundin, M.; Blomberg, E.; Tilton, R.D. Polymer dynamics in layer-by-layer assemblies of chitosan and heparin. Langmuir 2010, 26, 3242-3251.

31. Crouzier, T.; Boudou, T.; Picart, C. Polysaccharide-based polyelectrolyte multilayers. Curr. Opin. Colloid Interf. Sci. 2010, 15, 417-426.

32. Khopade, A.J.; Caruso, F. Investigation of the factors influencing the formation of dendrimer/polyanion multilayer films. Langmuir 2002, 18, 7669-7676.

33. Lvov, Y.; Ariga, K.; Ichinose, I.; Kunitake, T. Assembly of multicomponent protein films by means of electrostatic layer-by-layer adsorption. J. Am. Chem. Soc. 1995, 117, 6117-6123.

34. Lvov, Y.; Ariga, K.; Onda, M.; Ichinose, I.; Kunitake, T. A careful examination of the adsorption step in the alternate layer-by-layer assembly of linear polyanion and polycations. Colloid Surf. A 1999, 146, 337-346.

35. Rodahl, M.; Höök, F.; Fredriksson, C.; Keller, C.A.; Krozer, A.; Brzezinski, P.; Voinova, M.; Kasemo, B. Simultaneous frequency and dissipation factor QCM measurements of biomolecular adsorption and cell adhesion. Faraday Discuss. 1997, 107, 229-246.

36. Zhang, D.; Wang, K.; Sun, D.; Xia, X.; Chen, H. Potentiodynamic deposition of Prussian blue from a solution containing single component of ferricyanide and its mechanism investigation. J. Solid State Electrochem. 2003, 7, 561-566. 
37. Valota, A.T.; Kinloch, I.A.; Novoselov, K.S.; Casiraghi, C.; Eckmann, A.; Hill, E.W.; Dryfe, R.A.W. Electrochemical behavior of monolayer and bilayer grapheme. ACS Nano 2011, 5, 8809-8815.

38. Takahashi, S.; Anzai, J. Phenylboronic acid monolayer-modified electrodes sensitive to sugars. Langmuir 2005, 21, 5102-5107.

39. Li, H.; Guan, H.; Dai, H.; Tong, Y.; Zhao, X.; Qi, W.; Majeed, S.; Xu, G. An amperometric sensor for the determination of benzophenone in food packaging materials based on the electropolymerized molecular imprinted poly-o-phenylenediamine film. Talanta 2012, 99, 811-815.

40. Khramov, A.N.; Munos, J.; Collinson, M.M. Preparation and characterization of macroporous silicate films. Langmuir 2001, 17, 8112-8117.

41. Trouillon, R.; Combs, Z.; Patel, B.A.; O'Hare, D. Comparative study of the effect of various electrode membranes on biofouling and electrochemical measurements. Electrochem. Commun. 2009, 11, 1409-1413.

(C) 2013 by the authors; licensee MDPI, Basel, Switzerland. This article is an open access article distributed under the terms and conditions of the Creative Commons Attribution license (http://creativecommons.org/licenses/by/3.0/). 